\title{
Uranium and thorium in muscle tissue of fish taken from the southern Baltic
}

\author{
Piotr Szefer ${ }^{1}$, Krystyna Szefer ${ }^{1}$ \& Jerzy Falandysz ${ }^{2}$ \\ ${ }^{1}$ Department of Analytical Chemistry, Medical Academy; \\ al. K. Marksa 107, PL 80-416 Gdańsk, Poland \\ ${ }^{2}$ Veterinary Hygiene Research Station; ul. Kartuska 249, PL 80-125 Gdańsk, Poland
}

\begin{abstract}
The determination of $U$ and Th was carried out on pooled samples of muscle tissue of cod (Gadus morhua), herring (Clupea harengus), sprat (Sprattus sprattus) and some other species of fish caught in 1981 in the southern Baltic. The levels of U obtained in the present study are generally within the ranges presented by other authors for fish from different aquatic regions of the world. The concentrations of $U$ are similar to those found for Th in Baltic fish analysed. The concentration factors

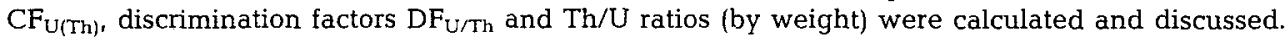
These coefficients were also compared with values determined in other Baltic organisms. Transfer of $\mathrm{U}$ and Th along a food chain from potential prey (diet) to fish as predator (consumer) was quantified with a transfer factor.
\end{abstract}

\section{INTRODUCTION}

The concentration and distribution of $U$ and Th in various environmental components, especially in marine food such as plankton, macroalgae, corals, molluscs, crustacea and ducks, have been investigated by several authors (Amiel et al., 1973; Bangera \& Patel, 1984; Blanchard \& Oakes, 1965; Blanchard et al., 1967; Chassard-Bouchaud, 1982a, 1983; Chassard-Bouchaud \& Escaig, 1984; Edgington et al., 1970; Flor \& Moore, 1977; Gvirtzman et al., 1973; Hamilton, 1980; Hodge et al., 1979; Holm \& Persson, 1980; Kharkar et al., 1976; Knauss \& Ku, 1983; Koide et al., 1982; Livingston \& Thompson, 1971; Miyake et al., 1970; Möller et al., 1983; Omura, 1976; Schroeder et al., 1970; Schwochau et al., 1976; Sugimura \& Mayeda, 1980; Szefer, 1987; Szefer \& Falandysz, 1983; Szefer \& Wenne, 1987; Thompson \& Livingston, 1970; Tsytsugina et al., 1973; Veeh \& Turekian, 1968). A survey of the literature (on the basis of 74 articles) concerning the concentration, discrimination and distribution of $U$ in marine biosphere has been presented by Szefer (1989). The migration of natural alpha-emitting radionuclides in the marine biosphere is an interesting problem from a radioecological and hygienic point of view. To anticipate effects of the causal release of radionuclides from nuclear power plants to the sea, it is important to understand the mechanisms by which stable isotopes like $U$ and $T h$ are concentrated and transported along the food chain of an ecosystem. Aquatic organisms are most likely to be affected by radionuclide release; hence data on their natural concentrations would be helpful as reference values (Edgington et al., 1970).

There is only limited information available on the concentration and distribution of $U$ in marine fish (Aten et al., 1961; Chassard-Bouchaud, 1982b; Hamilton, 1972; Ichikawa \& 
Ohno, 1981; Pentreath et al., 1979; Tsytsugina et al., 1973); a wide range of levels of $U$ in muscle of fish has been reported, i.e. from $<0.1$ to $40 \mathrm{ng} / \mathrm{g}$ on a wet-weight basis. Analysis of ${ }^{232} \mathrm{Th}$ resulted in negative results; it was computed that this isotope was present in concentrations lower than $0.5 \mathrm{ng} / \mathrm{g}$ wet weight in muscle of North Sea fish (Pentreath et al., 1979). Thus, it is important to know to what degree $U$ and $T h$ are incorporated in respective Baltic organisms. The aim of this paper is to report the concentrations of $U$ and $T h$ in muscle tissue of some commercially utilized fish of the southern Baltic. In order to estimate the degree of concentration, discrimination and transfer for $U$ and $T h$ in the Baltic environment, we utilized and recalculated their mean levels obtained here, as well as those recorded previously for other representatives of biosphere.

\section{MATERIALS AND METHODS}

The fish was caught by pelagic krill and/or herring trawls in July 1981 during the cruise of the R.V. "Profesor Siedlecki" and R.V. "Birkut". The localization of the sampling sites (fisheries) with the codes is presented in Figure 1. The material has also been utilized previously to determine eight trace metals after their separation by an anion exchange procedure (Szefer \& Falandysz, 1985). The $U$ and Th fractions collected were combined respectively to obtain composite eluates equivalent to pooled samples weights of maximum ca $500 \mathrm{~g}$ (on a wet weight basis). The sample preparation and details of the

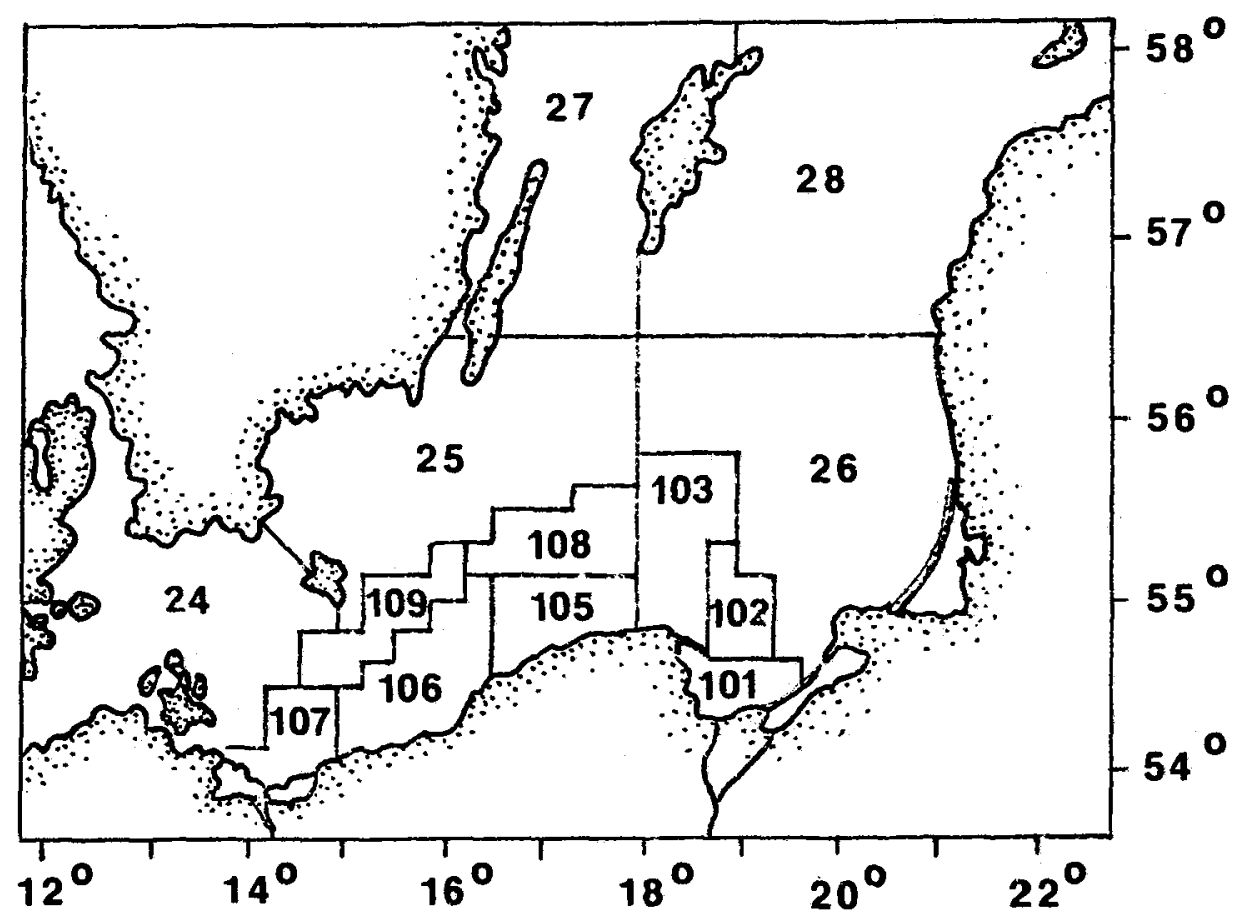

Fig. 1. Location of the sampling areas (fisheries) in the southern Baltic marked by the codes: 101 Gdańsk Bay, 102 Gdańsk Deep, 103 Wladyslawowskie fishery, 105 Ustecko-Łebskie fishery, 106 Kolobrzesko-Darlowskie fishery, 108 Slupsk Furrow fishery, 109 Bornholm S fishery 
analytical procedure have been presented elsewhere (Szefer, 1987; Szefer \& Falandysz, 1983, 1985). Briefly, ashed samples were converted into nitrates by evaporation with concentrated $\mathrm{HNO}_{3}$. The nitrate salts were dissolved in $8 \mathrm{MHNO}_{3}$ and then passed through an anion exchanger Dowex $1 \times 4\left(\mathrm{NO}_{3}^{-}\right)$to adsorb Th, eluted with $10 \mathrm{M} \mathrm{HCl}$. The eluent containing nitrates was evaporated to dryness and nitrates converted into chlorides by evaporation with concentrated $\mathrm{HCl}$. The chloride salts were dissolved in $1 \mathrm{M}$ $\mathrm{HCl}$ and aliquot was destined to determine some microelements by AAS method.

The remaining part of the solution was evaporated to dryness and dissolved with $9 \mathrm{M}$ $\mathrm{HCl}$. The solution was passed through an anion exchanger Dowex $1 \times 8\left(\mathrm{Cl}^{-}\right)$to isolate $\mathrm{U}$ from most of the other metallic ions which were analysed by AAS (Szefer \& Falandysz, 1985). The U and Th were determined spectrophotometrically with Arsenazo III (Szefer, 1987; Szefer \& Falandysz, 1983). The average limit of detection for $U$ and Th was $0.20 \mathrm{ng} /$ g w.w.

\section{RESULTS AND DISCUSSION}

As can be seen from Table 1 the mean levels of $U$ in the muscle tissue of cod (Gadus morhua), herring (Clupea harengus) and sprat (Sprattus sprattus) amounted to 0.30, 0.29 and $0.44 \mathrm{ng} / \mathrm{g}$ on a wet-weight basis, respectively. These species contained similar concentrations of Th, i.e. $0.41,0.38$ and $0.64 \mathrm{ng} / \mathrm{g}$ w.w., respectively. Among the other species analysed, the muscle levels of $U$ and Th varied between $0.22-0.42 \mathrm{ng} / \mathrm{g}$ and $0.43-1.6 \mathrm{ng} / \mathrm{g}$ w.w., respectively. Elevated levels of $U$ occurred in the whole specimens of stickleback (Gasterosteus aculeatus) $(2.6 \mathrm{ng} / \mathrm{g}$ w.w.). The muscle-levels of U (BLD-0.65 $\mathrm{ng} / \mathrm{g}$ w.w.) obtained in this study are comparable with the lowest values of 0.24 and $0.98 \mathrm{ng} / \mathrm{g}$ w.w. reported by other authors (Ichikawa \& Ohno, 1981; Tsytsugina et al., 1973) for Japanese and Black Sea fish, respectively.

The ratio of $\mathrm{Th} / \mathrm{U}$ (by weight) for Gadus morhua, Clupea harengus and Sprattus sprattus is near unity (on an average 1.37).

The mean levels of $U$ and $T h$ in fish and other Baltic organisms (Table 2) were utilized (after conversion: dry to wet weight) to calculate the concentration factor $\mathrm{CF}$ :

$$
\mathrm{CF}=(\mathrm{ng} \mathrm{U}(\mathrm{Th}) / \mathrm{g} \text { wet organism) } /(\mathrm{ng} \mathrm{U}(\mathrm{Th}) / \mathrm{g} \text { seawater) }
$$

To calculate this factor, the average southern Baltic water data for $U$ and $T h$ were taken from articles of Szefer (1977) and Bojanowski \& Szefer (1979). The salinity of surface water in this region was between 6.58 and $9.16 \%$ (on the average $7.7 \%$ ). The concentration of $U$ ranged from 0.65 to $1.06 \mu \mathrm{g} / 1$ (on the average $0.87 \mu \mathrm{g} /$ ) in open Baltic and from 0.26 to $1.06 \mu \mathrm{g} / \mathrm{l}$ (on the average $0.64 \mu \mathrm{g} / \mathrm{l}$ ) in coastal water. The correlation between the $U$ concentration and the salinity was 0.962 ; hence a dependence of the $C_{U}$ upon the salinity to be expected.

Table 3 presents values of $\mathrm{CF}_{\mathrm{U}}$ and $\mathrm{CF}_{\mathrm{Th}}$ for fish as well as for other representatives of Baltic biocenosis. These data reveal that the soft tissue of molluscs and whole specimens of Mesidothea entomon were characterized by maximum concentration of $U$ and $T h$, respectively, whilst in fish the smallest amounts of the two elements were concentrated. The mean $C_{\mathrm{U}}$ and $\mathrm{CF}_{\mathrm{Th}}$ values for fish muscle were 0.5 and 10 , respectively. For comparison, similar muscle value of $\mathrm{CF}_{\mathrm{U}}(0.3)$ was estimated by other authors (Ichikawa \& Ohno, 1981) for Japanese species of marine fish, i.e. for file fish (Stephanolepis cirrhifer), horse mackerel (Trachurus japonicus) and mackerel (Scomber japonicus). It is 
Table 1. Mean concentration of $U$ and Th in $\mathrm{ng} / \mathrm{g}$ on a wet weight basis ( \pm standard deviation) in muscle tissues of fish from the southern Baltic

\begin{tabular}{|c|c|c|c|c|}
\hline Species, locality (fishery) & No. & $\mathrm{U}$ & No. & Th \\
\hline \multicolumn{5}{|l|}{ Cod (Gadus morhua) } \\
\hline Gdańsk Bay 101* & $4(6)^{*}$ & $0.21 \pm 0.01$ & 6 & $0.38 \pm 0.06$ \\
\hline Gdańsk Deep 102 & $3(11)$ & $0.25 \pm 0.06$ & 11 & $0.63 \pm 0.05$ \\
\hline Wradyslawowskie (Northern part) 103 & $4(8)$ & $0.30 \pm 0.07$ & 8 & $0.33 \pm 0.05$ \\
\hline Wadyslawowskie (Southern part) 103 & $3(8)$ & $0.30 \pm 0.06$ & 6 & $0.32 \pm 0.07$ \\
\hline Kołobrzesko-Darłowskie 106 & $4(6)$ & $0.24 \pm 0.00$ & 6 & $0.40 \pm 0.11$ \\
\hline Słupsk Furrow 108 & $4 \quad(6)$ & $0.49 \pm 0.09$ & 10 & $0.34 \pm 0.06$ \\
\hline Bornholm S 109 & $4(10)$ & $0.32 \pm 0.06$ & 10 & $0.39 \pm 0.03$ \\
\hline Average & $26(55)$ & 0.30 & 55 & $0.41 \pm 0.06$ \\
\hline \multicolumn{5}{|l|}{ Herring (Clupea harengus) } \\
\hline Gdańsk Bay 101 & $5(60)$ & $0.25 \pm 0.06$ & $9(60)$ & $0.34 \pm 0.06$ \\
\hline Gdańsk Deep 102 & $1(10)$ & 0.21 & $2(20)$ & 0.30 \\
\hline Whadyslawowskie 103 & $2(20)$ & $\mathrm{BLD}^{+}-0.29$ & $5(35)$ & $0.44 \pm 0.12$ \\
\hline Ustecko-Łebskie 105 & $2(20)$ & BLD -0.65 & $3(30)$ & $0.37 \pm 0.14$ \\
\hline Kolobrzesko-Darłowskie 106 & $2(30)$ & 0.28 & $5(30)$ & $0.34 \pm 0.09$ \\
\hline Słupsk Furrow 108 & $1(30)$ & BLD & $4(30)$ & $0.55 \pm 0.01$ \\
\hline Bornholm S 109 & $1(10)$ & BLD & $2(30)$ & 0.22 \\
\hline Average & $14(180)$ & 0.29 & $30(235)$ & 0.38 \\
\hline \multicolumn{5}{|l|}{ Sprat (Sprattus sprattus) } \\
\hline Gdańsk Bay 101 & $1(4.5)$ & 0.44 & $3(45)$ & $0.82 \pm 0.06$ \\
\hline Kołobrzesko-Darłowskie 106 & $1(15)$ & BLD & $1(15)$ & 0.34 \\
\hline Slupsk Furrow 108 & - & - & $1(15)$ & 0.67 \\
\hline Bornholm S 109 & $1(15)$ & BLD & $1(15)$ & BLD \\
\hline Average & - & $\dot{-}$ & $6(90)$ & 0.64 \\
\hline \multicolumn{5}{|l|}{ Flounder (Platichthys flesus) } \\
\hline Gdańsk Bay 101 & $1(8)$ & 0.22 & $1(8)$ & 0.43 \\
\hline Kolobrzesko-Darłowskie 106 & - & - & 1 (9) & 0.53 \\
\hline \multicolumn{5}{|l|}{ Garfish (Belone belone) } \\
\hline Wladysławowskie 103 & $1(2)$ & 0.30 & $2(2)$ & 1.30 \\
\hline Kolobrzesko-Darłowskie 106 & $1(2)$ & 0.42 & $2(2)$ & 0.63 \\
\hline \multicolumn{5}{|l|}{ Eel (Anguilla anguilla) } \\
\hline Gdañsk Bay 101 & - & - & $1(1)$ & 0.66 \\
\hline \multicolumn{5}{|l|}{ Whiting (Merlangus merlangus) } \\
\hline Bornholm S 109 & - & - & $1(1)$ & 1.60 \\
\hline \multicolumn{5}{|l|}{ Salmon (Salmo salar) } \\
\hline Ustecko-Lebskie 105 & - & - & $1(1)$ & 0.50 \\
\hline \multicolumn{5}{|l|}{ Greater sand eel (Hyperoplus lanceolatus) ${ }^{++}$} \\
\hline Gdańsk Bay 101 & $1(10)$ & 0.44 & $2(10)$ & 1.20 \\
\hline \multicolumn{5}{|l|}{ Stickleback (Gasterosteus aculeatus) ${ }^{++}$} \\
\hline Gdańsk Bay 101 & $1(16)$ & 2,60 & $1(16)$ & 1.0 \\
\hline \multicolumn{5}{|l|}{ - Code of the fishery } \\
\hline \multicolumn{5}{|c|}{$\because$ Pooled samples; number of samples and total number of fish (in brackets) } \\
\hline \multirow{2}{*}{\multicolumn{5}{|c|}{$\begin{aligned}+ & \text { BLD - below limit of detection } \\
++ & \text { Whole fish }\end{aligned}$}} \\
\hline & & & & \\
\hline
\end{tabular}


Table 2. Concentrations of $U$ and $T h(\mu \mathrm{g} / \mathrm{g}$ on a dry weight basis) in various representatives of southern Baltic biocenosis*

\begin{tabular}{|lcc|}
\hline Representative of biocenosis & U & Th \\
\hline Seaweed & 0.23 & 0.24 \\
Zooplankton & 0.14 & 0.19 \\
Molluscs (whole) & 0.04 & 0.06 \\
Crustacea (whole): & 0.03 & 0.30 \\
$\quad$ Mesidothea entomon & 0.0013 & 0.0018 \\
Fish (muscle) & . Szefer \& Wenne (1987) and the present paper \\
\hline
\end{tabular}

Table 3. Mean concentration factors (CF) and discrimination factors (DF) for $U$ and Th in various representatives of southern Baltic biocenosis. To calculate the CF and DF factors, Baltic water data were taken from articles of Szefer (1977) and Bojanowski \& Szefer (1979)

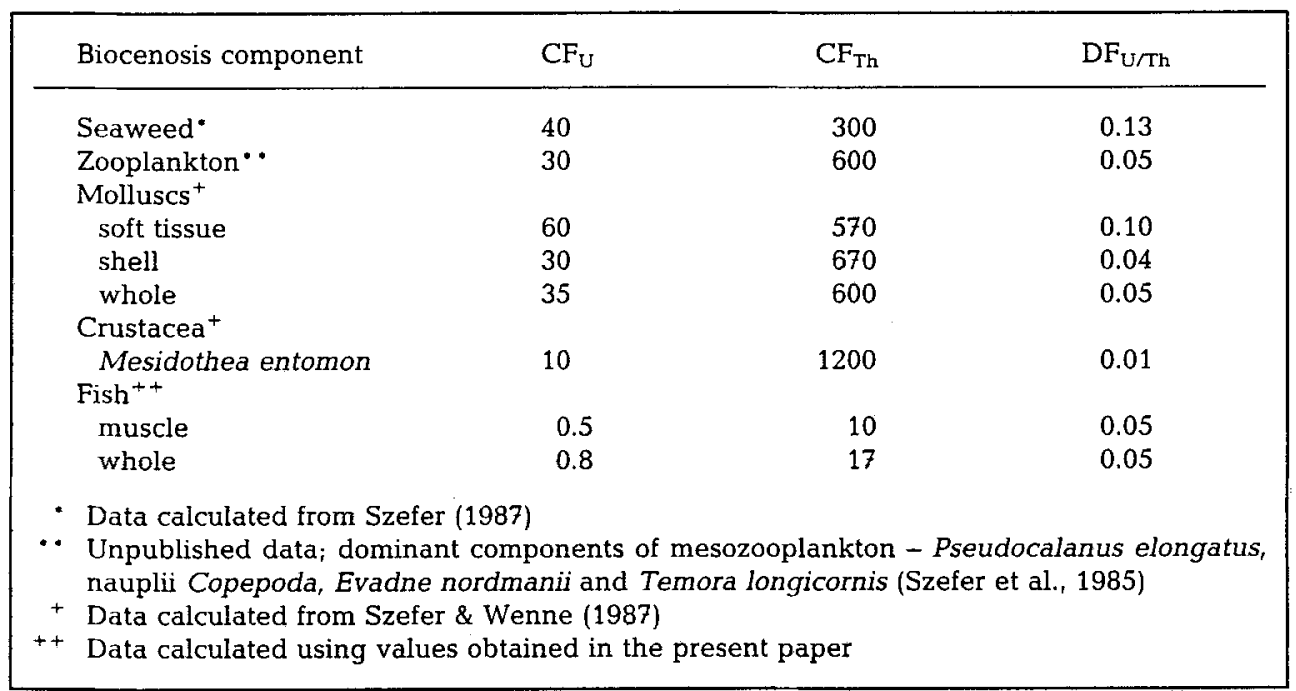

emphasized that the $\mathrm{CF}_{U}$ value obtained here is in the same order of magnitude as that reported in IAEA Technical Reports Series No. 247 (1985).

To determine the degree of discrimination of $U$ in respect to Th in Baltic organisms, the discrimination factor DF was estimated according to the formula:

$$
\mathrm{DF}=\left(\mathrm{C}_{\mathrm{U}} / \mathrm{C}_{\mathrm{Th}}\right)_{\mathrm{c}} /\left(\mathrm{C}_{\mathrm{U}} / \mathrm{C}_{\mathrm{Th}}\right)_{\mathrm{s}}
$$

where $\left(\mathrm{C}_{\mathrm{U}} / \mathrm{C}_{\mathrm{Th}}\right)_{\mathrm{c}}$ and $\left(\mathrm{C}_{\mathrm{U}} / \mathrm{C}_{\mathrm{Th}}\right)_{\mathrm{s}}$ are the concentration ratios of $\mathrm{U}$ to $\mathrm{Th}$ in organisms and seawater, respectively.

The results in Table 3 show that analysed organisms preferentially discriminate Th over $\mathrm{U}$ (all $\mathrm{DF} \mathrm{U}_{\mathrm{Th}}$ values lower than unity), i.e. they exhibit a stronger ability to adsorb and/or take up Th as compared to $U$ (with respect to seawater).

The $U$ and $T h$ transfer along the trophic levels of the food chain, i.e. from potential 
prey (diet) to fish (consumer) was quantitatively estimated by the transfer factor TF (Amiard et al., 1980):

$$
\mathrm{TF}=\frac{\mathrm{C}_{\mathrm{c}}}{\mathrm{C}_{\mathrm{p}}}
$$

where $\mathrm{C}_{\mathrm{c}}$ and $\mathrm{C}_{\mathrm{p}}$ mean the $\mathrm{U}$ and Th concentration (expressed on dry weight basis) in consumer and diet, respectively.

Helpful information concerning the food habits of fish analysed in the calculations was applied. According to the data obtained by Rutkowicz (1982) and Ciegglewicz et al. (1972), cod (Gadus morhua) feed on benthic invertebrates, e.g. molluscs and crustacea. Specimens of Gadus morhua (length body $>45 \mathrm{~cm}$ ) caught in spring in the southern Baltic contained in their alimentary tracts mainly specimens of herring (Clupea harengus), sprat (Sprattus sprattus) (59.5 percentage by weight) and Mesidothea entomon (4.7\%). Greater mass contribution of Mesidothea entomon (13\%) was found in the food content of small specimens of cod (Gadus morhua) $(15-25 \mathrm{~cm})$. The food content of herring (Clupea harengus) and sprat (Sprattus sprattus) consisted mainly of zooplanktonic organisms Temora longicornis and Pseudocalanus elongatus (Cięglewicz et al., 1972).

Bearing the above-mentioned information in mind, the degree of transfer of $U$ and $T h$ along the trophic levels was estimated (Table 4). Approximately equal or lower than unity TF values suggest that there is no biomagnification of these elements along the food chain steps leading to fish from their potential diet.

Table 4. Mean transfer factors (TF) for $U$ and Th in fish with respect to lower trophic levels in southern Baltic ecosystem

\begin{tabular}{|lll|}
\hline Trophic relation & & \\
Consumer - potential prey & $\mathrm{TF}_{\mathrm{U}}$ & $\mathrm{TF}_{\mathrm{Th}}$ \\
\hline Gadus morhua - Clupea harengus & 1.30 & 1.40 \\
Gadus morhua - Mesidothea entomon & 0.05 & 0.01 \\
Gadus morhua - molluscs & 0.04 & 0.04 \\
Clupea harengus - zooplankton & 0.01 & 0.01 \\
Sprattus sprattus - zooplankton & 0.01 & 0.01 \\
Hyperoplus lanceolatus - zooplankton & $0.02^{*}$ & $0.03^{*}$ \\
- Values calculated using the concentration of $\mathrm{U}$ and Th in whole fish & \\
\hline
\end{tabular}

\section{LITERATURE CITED}

Amiard, J.-C., Amiard-Triquet, C., Metayer, C., Marchand, J. \& Ferre, R., 1980. Etude du transfert de $\mathrm{Cd}, \mathrm{Pb}, \mathrm{Cu}$ et $\mathrm{Zn}$ dans les chaînes trophiques neritiques et estuariennes. I. Etat dans l'estuaire interne de la Loire (France) au cours de l'été 1978. - Wat. Res. 14, 665-673.

Amiel, A. J., Miller, D. S. \& Friedman, G. M., 1973. Incorporation of uranium in modern corals. Sedimentology 20,523-528.

Aten, A. H. W., Dalenberg, J. W. \& Bakkum, W. C. M., 1961. Concentration of uranium in sea fish. Hith Phys. 5, 225-226. 
Bangera, V. S. \& Patel, B., 1984. Natural radionuclides in sediment and in arcid clam (Anadara granosa L.) and gobiid mudskipper (Boleophthalmus boddaerti Cuv. \& Va.). - Indian J. mar. Sci. 13,5-9.

Blanchard, R. L. \& Oakes, D., 1965. Relationship between uranium and radium in coastal marine shells and their environment. - J. geophys. Res. 70, 2911-2921.

Blanchard, R. L., Cheng, M. H. \& Potratz, H. A., 1967. Uranium and thorium series disequilibria in recent and fossil marine molluscan shells. - J. geophys. Res. 72, 4745-4757.

Bojanowski, R. \& Szefer, P., 1979. Uranium in the Baltic water. - Stud. Materiały Oceanol. 26, 253-274 (in Polish, with an English abstract).

Chassard-Bouchaud, C., 1982a. Concentration de l'uranium par les Crustacés. Etude structurale, ultrastructurale et microanalytique par émission ionique secondaire et par spectrographie des rayons X. - C. r. Acad. Sci., Paris (Sér. 3.) 294, 919-924.

Chassard-Bouchaud, C., 1982b. On the occurrence of uranium, ruthenium, cesium and thulium in diseased fish: a microanalytical ion microscopy study. - Electronmicroscopy 3, 405-406.

Chassard-Bouchaud, C., 1983. Cellular and subcellular localization of uranium in the crab Carcinus maenas: a microanalytical study. - Mar. Pollut. Bull. 14, 133-136.

Chassard-Bouchaud, C. \& Escaig, F., 1984. Uptake, storage and excretion of uranium by Mytilus edulis. A structural, ultrastructural and microanalytical study by secondary ion emission and $\mathrm{X}$ ray spectrometry. - J. Phys. (Suppl. au Nr 2) 45, 545-548.

Cięglewicz, W., Załachowski, W., Szypuła, J., Krzykawski, S. \& Krzykawska, I., 1972. Food habits of commercial fish of the southern Baltic. In: Marine ecosystems. Ed. by K. Siudziński, MIR, Gdynia, $2,363-450$.

Edgington, D. N., Gordon, S. A., Thommes, M. M. \& Almodovar, L. R., 1970. The concentration of radium, thorium and uranium by tropical marine algae. - Limnol. Oceanogr. 15, 945-955.

Flor, T. H. \& Moore, W. S., 1977. Radium/calcium and uranium/calcium determinations for Western Atlantic reef corals. - Proc. 3rd int. Coral Reef Symp. Miami 2, 555-561.

Gvirtzman, G., Friedman, G. M. \& Miller, D. S., 1973. Control and distribution of uranium in coral reefs during diagenesis. - J. sedim. Petrol. 43, 985-997.

Hamilton, E. I., 1972. Concentration of uranium in man and his diet. - Hlth Phys. 22, 149-153.

Hamilton, E. I., 1980. Concentration and distribution of uranium in Mytilus edulis and associated materials. - Mar. Ecol. Prog. Ser. 2, 62-73.

Hodge, V. F., Koide, M. \& Goldberg, E. D., 1979. Particulate uranium, plutonium and polonium in the biogeochemistries of the coastal zone. - Nature, Lond. 277, 206-209.

Holm, E. \& Persson, B. R. R., 1980. Behaviour of natural (Th, U) and artificial ( $\mathrm{Pu}, \mathrm{Am}$ ) actinides in coastal waters. In: Marine radioecology (Proc. 3rd NEA Seminar., Tokyo, 1979). OECD, Paris, $237-243$.

IAEA, 1985. Sediment $K_{d} S$ and concentration factors for radionuclides in the Marine Environment. Tech. Rep. Ser., IAEA 247, 1-73.

Ichikawa, R. \& Ohno, S., 1981. Uranium content in marine fish. - Bull. Jap. Soc. scient. Fish. 47, 289.

Kharkar, D. P., Thomson, J., Turekian, K. K. \& Forster, W. O., 1976. Uranium and thorium decay series nuclides in plankton from the Caribbean. - Limnol. Oceanogr. 21, 294-299.

Knauss, K. \& Ku, T.-L., 1983. The elemental composition of decay-series radionuclide content of plankton from the East Pacific. - Chem. Geol. 39, 125-145.

Koide, M., Lee, D. S. \& Goldberg, E. D., 1982. Metal and transuranic records in mussel shells, byssal threads and tissues. - Estuar. coast. Shelf Sci. 15, 679-695.

Livingston, H. D. \& Thompson, G., 1971. Trace element concentrations in some modern corals. Limnol. Oceanogr. 16, 786-796.

Miyake, Y., Sugimura, Y. \& Mayeda, M., 1970. The uranium content and the activity ratio ${ }^{234} U /{ }^{238} U$ in marine organisms and sea water in the western North Pacific. - J. oceanogr. Soc. Jap. 26, 123-129.

Möller, H., Schneider, R. \& Schnier, Ch., 1983. Trace metal and PCB content of mussels (Mytilus edulis) from the southwestern Baltic Sea. - Int. Revue ges. Hydrobiol. 68, 633-647.

Omura, A., 1976. Thorium and protactinium isotopes in some present-day hermatypic corals and their implications to dating. - Trans. Proc. palaeont. Soc. Japan 101, 271-290.

Pentreath, R. J., Lovett, M. B., Harvey, B. R. \& Ibbett, R. D., 1979. Alpha-emitting nuclides in commercial fish species caught in the vicinity of Windscale, United Kingdom, and their radiologi- 
cal significance to man. Biological implications of radionuclides released from nuclear industries. IAEA, Vienna, 2, 227-245.

Rutkowicz, S., 1982. Encyklopedia Ryb Morskich. Wydawnictwo Morskie, Gdynia. 663 pp.

Schroeder, J. H., Miller, D. S. \& Friedman, G. M., 1970. Uranum distribution in recent skeletal carbonates. - J. sedim. Petrol. 40,672-681.

Schwochau, K. Astheimer, L., Schenk, H. J. \& Schmitz, J., 1976. Verfahren zur Gewinnung von Uran aus dem Meerwasser. - Ber. Kernforschungsanl. Jülich 1415, 38-45.

Sugimura, Y. \& Mayeda, M., 1980. The uranium content and the activity ratio ${ }^{234} \mathrm{U} /{ }^{238} \mathrm{U}$ in sea water in the Pacific Ocean. In: Isotope marine chemistry. Ed. by E. D. Goldberg, Y. Horibe \& $\mathrm{K}$. Saruhashi. Uchida Rokakuho Publ. Co., Tokyo, 211-246.

Szefer, P., 1977. Investigations on the uranium and thorium contents of Vistula estuary water, also inshore water of the Gulf of Gdańsk. - Stud. Materialy Oceanol. 17, 379-392 (in Polish, with an English abstract).

Szefer, P., 1987. Concentration of uranium and thorium by some Baltic seaweeds and lake plants. Mar. Pollut. Bull, 18, 439-442.

Szefer, P., 1989. Uranium and its isotopes in marine biocenosis, - Stud. Materiały Oceanol. (in Polish, with an English abstract). (In press)

Szefer, P. \& Falandysz, J., 1983. Uranium and thorium content in long-tailed ducks (Clangula hyemalis L.) from the Gdańsk Bay. - Sci. Total Environ. 29, 269-276.

Szefer, P. \& Falandysz, J., 1985. Trace metals in muscle tissue of fish taken from the southern Baltic. - Z. Lebensmittelunters. - Forsch. 181, 217-220.

Szefer, P. \& Wenne, R., 1987. Concentration of uranium and thorium in molluscs inhabiting Gdańsk Bay, Baltic Sea. - Sci. Total Environ. 65, 191-202.

Szefer, P, Skwarzec, B. \& Koszteyn, J, 1985. The occurrence of some metals in mesozooplankton taken from the southern Baltic. - Mar. Chem. 17, 237-253.

Thompson, G. \& Livingston, H. D., 1970. Strontium and uranium concentrations in aragonite precipitated by some modern corals. - Earth Planet. Sci. Lett. 8, 439-442.

Tsytsugina, V. G., Risik, N. S. \& Lazorenko, G. E., 1973. Concentration and microdistribution of uranium in marine organisms under natural conditions. In: Artificially and naturally produced radionuclides in aquatic biocenosis. Ed. by G. G. Polikarpov. Naukova Dumka, Kiev, 58-94.

Veeh, H. H. \& Turekian, K. K., 1968. Cobalt, silver, and uranium concentrations of reef-building corals in the Pacific Ocean. - Limnol. Oceanogr. 13, 304-308. 